\title{
Climate Change and Energy in the Arctic- The Role of the European Union
}

\author{
Natalie Dobson \\ PhD Fellow, School of Law, UcwosL, Utrecht University, Utrecht, \\ The Netherlands
}

\section{Seline Trevisanut}

Professor of International Law and Sustainability, School of Law, UCwOSL, Sustainable Ocean Project (ERC StG grant agreement No 639070), Utrecht University, Utrecht, The Netherlands

\begin{abstract}
The effects of global warming in the Arctic region present a particular challenge for the European Union (EU), which seeks to profile itself as a leader in responding to climate change. Although the EU strives to prioritize climate protection, the Arctic region remains one of the EU's major suppliers of energy, particularly oil and gas. The EU must thus strike a balance between climate change mitigation and adaptation, and energy security. The present article analyses the developments of the Eu position in this field, particularly in light of the COP 21 negotiations, and the more recent 2016 Integrated European Union Policy for the Arctic. In doing so it seeks to explore to what extent the EU truly is fulfilling its own leadership aspirations in the field of climate change and energy in the Arctic.
\end{abstract}

\section{Keywords}

Arctic - climate change - EU climate leadership - EU energy policy - energy security 


\section{Introduction}

It is well established that the Arctic region is particularly sensitive to climate change. The Arctic states have recognized that 'the Arctic is warming considerably faster than other regions of the globe, leading to fundamental changes to the environment and human living conditions in both the Arctic and around the world. The efforts towards mitigation and adaptation to climate change in the Arctic are particularly supported by the European Union (EU), which has taken a leading role internationally in this field. In the 2016 Joint Communication on an Integrated European Union Policy for the Arctic, ${ }^{1}$ the European Commission and the High Representative of the European Union for Foreign Affairs and Security Policy clearly express their focus on climate and environmental issues in the Arctic.

This last communication represents an interesting development in the $\mathrm{EU}$ Arctic and energy policies when compared to previous policy documents. The interest of the $\mathrm{EU}$ in the Arctic has always been manifold and has progressively increased in the last fifteen years. The Arctic region remains one of the major suppliers of energy, mainly oil and gas, for the EU. The strategic importance of the Arctic region for the Eu energy security clearly emerged in the policy documents of $2008^{2}$ and 2012. ${ }^{3}$ The 2016 Communication represents a focus-shift in the EU Arctic policy, at least in terms of declared goals. With its increased emphasis on climate protection and research, the new 'integrated' EU Arctic Policy is strongly framed around environment and sustainability, rather than strategic geo-political interests.

The present article analyses the development of the EU positions in the field of mitigation and adaptation to climate change, and assesses them in the Arctic context. It then looks at how the Eu's self-declared climate leadership is affecting the EU energy policy, specifically in relation to the management and exploitation of hydrocarbons in the Arctic. Analyzing these trends in their broader context, this article considers the extent to which the EU truly is fulfilling its own leadership aspirations in the field of climate change and energy in the Arctic context.

1 'An Integrated European Union Policy for the Arctic' JoIN(2016) 21 final, 24 April 2016 (JOIN(2016) 21).

2 European Commission, 'The European Union and the Arctic Region' сом(2008) 736 final, 20 November 2008 (сом(2008) 736).

3 European Commission, 'Developing a European Union Policy towards the Arctic Region: progress since 2008 and next steps' JOIN(2012) 19 final, 26 June 2012 (JOIN(2012) 19). 


\section{The EU as a Self-proclaimed Climate Leader}

Over the past decades the EU has become increasingly visible as a global environmental actor, particularly in the field of climate change, where it has been keen to profile itself as a leader in climate protection. ${ }^{4}$ Indeed, as a regional organization, the $\mathrm{EU}$ has a unique status as an independent party to the United Nations Framework Convention on Climate Change (UNFCCC) ${ }^{5}$ and the Kyoto Protocol, ${ }^{6}$ alongside its Member States. Throughout the extensive negotiation period, the EU has sought to 'set the example', by committing to a $20 \%$ emissions reduction target by 2020 , irrespective of whether an international agreement was concluded. ${ }^{7}$ This went above the target set for the second Kyoto commitment period, and was, in the Eu's own words, 'by far the most ambitious commitment by any country or group of countries in the world for the post-2012 period'. 8 Leaning further on public opinion, the EU then pledged to increase its $\mathrm{CO}_{2}$ reduction target from $20 \%$ to $30 \%$ by 2020 if other major emitting countries also committed to undertake their 'fair share' of global emissions. ${ }^{9}$

4 See for further discussion: E Morgera and GM Duran, Environmental Integration in the EU's External Relations (Hart Publishing, Oxford, 2012); T Delreux, 'The EU as an Actor in Global Environmental Politics' in A Jordan and C Adelle (eds), Environmental Policy in the EU. Actors, Institutions and Processes (3rd Edition, Routledge, London, 2013) 287-305; RKW Wurzel and J Connelly (eds), The European Union as a Leader in International Climate Change Politics (Routledge, London, 2011); S Oberthur, 'The Role of the EU in Global Environmental and Climate Governance', in J-U Wunderlich and DJ Bailey (eds), The European Union and Global Governance. A Handbook (Routledge, London, 2009) 192-209; S Oberthür and CR Kelly, 'EU Leadership in International Climate Policy: Achievements and Challenges' (2008) 43 The International Spectator $3^{-} 5^{0}$.

5 United Nations Framework Convention on Climate Change (New York, 9 May 1992, in force 21 March 1994) Un Doc FCCC/INFORMAL/84 (UNFCCC).

6 Kyoto Protocol to the United Nations Framework Convention on Climate Change (Kyoto, 11 December 1997, in force 16 February 2005) Un Doc FCCC/CP/1997/7/Add.1, Dec. 10, 1997 (Kyoto Protocol).

7 European Commission, 'Towards a comprehensive climate change agreement in Copenhagen' (Communication) Сом(2009)39 final, 28 January 2009, (Сом(2009)39) 4.

8 Ibid.

9 The original commitments are contained in the Kyoto Protocol. The collective commitment was divided amongst Eu Member States by the Effort Sharing Decision, which takes into account the different energy needs according to the varying levels of development, Parliament and Council (EU) Decision 406/2009/EC on the effort of Member States to reduce their greenhouse gas emissions to meet the Community's greenhouse gas emission reduction commitments up to 2020 [2009] OJ L 140/136. 
More recently, the EU and its Member States also played a central role in the negotiations at the Conference of the Parties (COP) 21 leading up to the Paris Agreement. ${ }^{10}$ Nurturing 'strategic alliances', it led the formation of the 'High Ambition Coalition' with countries sharing its climate protection vision. ${ }^{11}$ According to the EU Climate Action and Energy Commissioner, Miguel Arias Cañete, this was a 'masterplan' that changed the game in Paris, allowing the EU and its allies to 'make history' and 'shape the Paris deal.'12 Setting an example once again, the EU was the first 'major economy' to submit its intended contribution under the Paris Agreement, pledging a $40 \%$ domestic reduction commitment by 2030 compared to 1990 levels. ${ }^{13}$ Looking further ahead, it has also committed to an $80 \%$ emission reduction by 2050 compared to 1990 levels, with $20 \%$ of the EU budget to be devoted to climate-related objectives. ${ }^{14}$

With such ambitious objectives, it would seem consistent that the EU extends its proactive approach to the Arctic region, an area it has recognized as 'particularly vulnerable'. ${ }^{15}$ However, a closer look at the EU positions reveals a more complex picture of competing interests, and one can question whether the Union's self-proclaimed leadership role really extends to the Arctic region. In analyzing this issue, the following section considers the role of climate protection in the development of the EU's first 'integrated' Arctic policy.

10 The Paris Agreement (Paris, 12 December 2015, in force 4 November 2016) Un Doc FCCC/ CP/2015/L.9/Rev.1 (Paris Agreement).

11 United Nations, 'Climate Summit 2014: Catalyzing Action' available at: http://www .un.org/climatechange/summit/2014/og/2014-climate-change-summary-chairs-summary/; accessed 12 April 2015.

12 MA Cañete, 'Historic Climate Deal in Paris' (Speech at the press conference on the results of COP21 climate conference in Paris (Speech 15/6320 Europa website 2015), available at http://europa.eu.int; accessed 25 May 2016.

13 European Commission, 'Environment Council approves the EU's intended nationally determined contribution to the new global climate agreement', available at: http:// ec.europa.eu/clima/news/articles/news_2015030601_en.htm; accessed 6 March 2015. See, UnfCCC, Draft Decision -/CP.21, 'Paris Agreement', 7 FCCC/CP/2015/L.9/Rev.1 (2015) (Paris Agreement), Art. 4(2).

14 European Commission, 'A Roadmap for moving to a competitive low carbon economy in 2050' (Communication) Сом(2011) 112 final, 8 March 2011, 4.

15 European Commission, 'An EU strategy on adaption to climate change' (Communication) $\operatorname{com}(2013) 216$ final, 16 April 2013, 2. 


\section{Extending Climate Leadership to the Arctic Region? Towards an EU Integrated Approach}

At first glance, it may not seem entirely intuitive that the EU should have a leading role to play in climate-related Arctic policy. In geographical terms, the EU has some representation in the area, with EU Member States Denmark (Greenland), Sweden and Finland, as well as European Economic Area (EEA) members, Norway and Iceland, all having Arctic territories; however, these states remain independent actors. As a Union, the importance of the EU's role lies in its indirect contribution to climate change risks in the Arctic. Indeed, the 2010 Arctic Footprint Policy Assessment concluded that the EU has a significant impact on the socio-economic and environmental aspects of the Arctic region.' ${ }^{16}$ Particularly in relation to climate change, the report noted that greenhouse gases (GHGs) emitted by the EU contributed to an EU footprint of $15 \%$ of the global impact in the Arctic, its final demand for products from the oil and gas industry amounting to $24 \% .{ }^{17}$ More dramatically, the report also found that the EU contributed a $59 \%$ share of black carbon emissions in the region. ${ }^{18}$ As black carbon deposition increases the rate of melting in snow and ice, this should have clear policy implications for the EU's Arctic agenda.

Despite its direct and indirect relationship with the Arctic, the EU is a relative newcomer to the field, only deciding to develop a Community Arctic policy in 2008. 19 The main impetus for this new interest was concern regarding the impact of climate change on the 'geo-strategic dynamics' of the Arctic. ${ }^{20}$ These changing dynamics were the result of rapidly melting polar ice-caps, which continued to create new waterways and increase the accessibility of the 'enormous' hydrocarbon resources in the region. In response, the 2008 Paper of the High Representative and European Commission on Climate Change and International Security noted the 'increasing need to address the growing debate over territorial claims and access to new trade routes', which 'challenge Europe's ability to effectively secure its trade and resource interests in the

16 Ecologic Institute, Report on 'EU Arctic Footprint and Policy Assessment', Berlin, 2010, 1; available at: http://arctic-footprint.eu /sites/default/files/AFPA_Final_Report.pdf; accessed 25 May 2016.

17 Ibid., at p. 3 .

18 Ibid., at p. 6.

19 See High Representative and European Commission, 'Climate Change and International Security', Paper S113/o8, 14 March 2008.

$20 \quad$ Ibid., at p. 8. 
region [...].'21 The 2008 Paper thus suggested the creation of an 'EU Arctic policy based on the evolving geo-strategy of the Arctic region.' ${ }^{22}$ This was initiated in a Commission Communication a few months later, which, concerned with the role of climate change as a 'threats multiplier', set out key EU interests and points of action in the Arctic. ${ }^{23}$ The 2008 Communication is discussed further below.

We thus see that while the development of the Eu's Arctic policy was prompted by climate change, its original objectives appeared more focused on trade and resource interests than they were on environmental protection. In fact, hydrocarbon resources and their extraction are key contributors to climate change. ${ }^{24}$ In addition, although allowing maritime transport through Arctic waterways would shorten the overall transport routes, it is likely to further harm the fragile Arctic ecosystem, which in turn has knock-on effects on the global climate system. ${ }^{25}$ These conflicting interests raise the question whether the EU really has been 'leading by example', as it proclaimed at the COP21. In analyzing this issue, the following section will examine the development of the EU's 'integrated approach' to combatting climate change in the Arctic.

\section{Climate Change in the Development of the EU's Arctic Policy}

Having established its strategic interest in the Arctic, the E U has struggled somewhat to position itself as a global Arctic actor. ${ }^{26}$ In 2008 the Commission first set out the key EU policy objectives in the Communication on the European

\footnotetext{
$21 \quad$ Ibid.

22 Ibid., at p. 11.

$23 \operatorname{com}(2008) 736$ (n 2).

24 See further, Eniscuola Energy and Environment, 'Hydrocarbons and Climate Change', available at: http://www.eniscuola.net/en/argomento/energy-knowledge/sustainableuse-of-resources/hydrocarbons-and-climate-change/; accessed 25 May 2016.

25 See $\operatorname{com}(2008) 763$ (n 2), at para. 3.3: 'Transport: Eu Member States have the world's largest merchant fleet and many of those ships use trans-oceanic routes. The melting of sea ice is progressively opening opportunities to navigate on routes through Arctic waters. This could considerably shorten trips from Europe to the Pacific, save energy, reduce emissions, promote trade and diminish pressure on the main trans-continental navigation channels. But serious obstacles remain, including drift ice, lack of infrastructure, environmental risks and uncertainties about future trade patterns.

26 See further, e.g., K Hossain, 'EU Engagement in the Arctic: Do the Policy Responses from the Arctic States Recognise the EU as a Legitimate Stakeholder?' (2015) 6(2) Arctic Review on Law and Politics 89-110; A Raspotnik and K Keil, 'Further Steps Towards a Comprehensive EU Arctic Policy: Is the EU Getting There?', The Arctic Institute (5 July 2012), available at: http://www.thearcticinstitute.org/further-steps-towards-comprehensive-eu/; accessed 25 May 2016.
} 
Union and the Arctic Region. ${ }^{27}$ As the first concern on the list, climate change was framed to feature prominently. The various proposals for action included strengthening 'cooperation on improving primary energy savings, energy efficiency and the use of renewable energies in the Arctic', and 'strengthening international efforts to mitigate climate change'. In terms of its own contribution to the problem, the Communication noted that, 'where strategies and projects of the EU affect the Arctic' the EU should 'take account of environmental impacts before decisions are made', and 'share experience with the Arctic states.' ${ }^{28}$

Yet, under the heading, 'promoting the sustainable use of resources', the 2008 Communication notes its interest in the 'large untapped hydrocarbon reserves', including those in offshore resources inside the EEzs of Arctic states. These resources could 'contribute to enhancing the Eu's security of supply concerning energy and raw materials in general. ${ }^{29}$ Exploitation would be slow, 'since it presents great challenges and entails high costs due to harsh conditions and multiple environmental risks. ${ }^{30}$ The Communication expressed a special interest in the maintenance of a 'level playing field' and 'reciprocal market access'. At the same time, it encouraged the observance of the 'highest possible environmental standards', as well as the 'introduction of binding international standards, building inter alia on the guidelines of the Arctic Council and relevant international conventions'.

The EU has thus never masked its interest in accessing energy and raw materials as a key driver for cooperation with other states. This it sought to marry with its sustainability objectives through the promotion of high environmental protection standards for marine pollution and resource extraction in international fora such as the Arctic Council and the Imo. ${ }^{31}$ Arguably however,

$27 \operatorname{com}(2008) 763\left(\mathrm{n} 2_{2}\right)$, at para. 2.1.

28 Ibid.

$29 \quad$ Ibid., at para. 3.1.

$30 \quad$ Ibid. A key action point was to improve the 'foundations for long-term cooperation, particularly with Norway and the Russian Federation' to facilitate the 'sustainable and environmentally friendly exploration, extraction and transportation of Arctic hydrocarbon resources'.

31 This remains an open-ended objective. For example, the EU's pledge to 'explore support for designating some Arctic navigation routes as particularly sensitive sea areas under IMO rules, if proposed by any of the Arctic coastal states' ( $\operatorname{com}(2008) 763$ (n 2), at para. 3.3) did not find much traction. To date, the Arctic waters are yet to be recognised as a 'Particularly Sensitive Sea Area' (PSSA) by the IMO, despite the advice of the Marine Shipping Assessment (AMSA)II(D) Report commissioned by the Arctic Council Working Group. See, Arctic Council, 'Status on Implementation of the AMSA 2009 Report Recommendations' (April 2015), available at: http://www.pmel.noaa.gov/arctic-zone/ 
such an approach treats the symptoms rather than the cause. Although the EU acknowledged its own role in contributing to climate change, it really only addressed this through encouraging impact assessments and resolving to assess the effectiveness of its own policies. ${ }^{32}$ Improvements in energy efficiency, renewables and emission reductions were somewhat vaguely to be achieved through 'strengthening cooperation' with other States. ${ }^{33}$

It is arguable whether the developments throughout the following years have done much to strengthen the Eu's diffuse Arctic policy. More generally, the EU has struggled to secure observer status at the Arctic Council, an issue hampered by a dispute with Canada over the EU's import ban on seals and seal products. ${ }^{34}$ It also failed to garner sufficient support for its 2008 proposal for an international Arctic Treaty, which, it has been suggested 'was perceived by some as being dismissive of the sovereign rights of the eight Arctic states'.35 Furthermore, 'the Commission's pursuit of an 'enhanced role' in Arctic governance' gave some the impression of being 'both ignorant and overly assertive'. ${ }^{36}$ Looking at more specific policy documents, the Commission and High Representative's 2012 Communication built on the 2008 objectives, but with

detect/documents/; accessed 25 May 2016. For an overview of the current PSSAs see: http://www.imo.org/en/OurWork/Environment/PSSAs/Pages/Default.aspx; accessed 25 May 2016. The Arctic region continues to have very few marine protected areas (MPAs), with only $1.94 \%$ of the Arctic Waters being covered by OSPAR MPAs in 2014. See further, IU Jakobsen, Marine Protected Areas in International Law: An Arctic Perspective (Brill, Leiden, 2016) 373 .

$32 \operatorname{com}(2008) 763(\mathrm{n} 2)$, at para. 2.1.

33 Ibid.

34 See, Arctic Council Secretariat, 'Observers', available at: http://www.arctic-council.org/ index.php/en/about-us/arctic-council/observers; accessed 28 July 2016. The ban was the subject of litigation before the Appellate Body of the wто; see, wто, European Communities - Measures Prohibiting the Importation and Marketing of Seal Products (22 May 2014) AB-2014-1 and AB-2014-2. The EU ban has also been the subject of litigation before the Court of Justice of the European Union (CJEU) in the Case C-389/13P Inuit Tapiriit Kanatami et al. v. European Commission [2015] ECR I-535, where the CJEU upheld the validity of the measure. See for further analysis of EU policy, N Selheim, 'The Neglected Tradition? - The Genesis of the EU Seal Products Trade Ban and Commercial Sealing' (2013) 5 Yearbook of Polar Law 417-450.

35 D Depledge, 'The European Union in the Arctic' (worldpolicy.org, 24 June 2015) http:// www.worldpolicy.org/blog/2015/06/24/european-union-arctic; see also A Airoldi, The European Union and the Arctic Developments and Perspectives 2010-2014 (Nordic Council of Ministers, 2014), 12, available at: http://norden.diva-portal.org/smash/get/diva2:771155/ FULLTEXTo1.pdf; accessed 28 July 2016.

Ibid. 
few substantive changes, and has been criticized as 'statements of fact rather than commitments to action, which appear to be in great part a continuation or intensification of existing activities at EU, bilateral or multilateral level.' ${ }^{37}$

The more recent 2014 European Parliament Resolution on the EU Strategy for the Arctic emphasizes the 'economic opportunities and the variety of industries in the Arctic and sub-Arctic regions', including 'tourism, maritime industry and shipping, renewable energy [...] gas and oil, offshore industry, forestry and wood-based industries, mining [and] transport services'. Not all of these industries are equally conducive to climate protection. Notably, the 2014 Resolution does make indirect reference to the EU's influence on climate change in the Arctic, recalling 'the position of the EU as a main consumer of Arctic natural gas.' ${ }^{38}$ However, it considers this to be 'an important bridge element for the shift to a low-carbon economy in the future'. Although natural gas does emit far less $\mathrm{CO}_{2}$ than oil or coal if combusted under the correct conditions, it remains a key fossil fuel contributing to climate change. ${ }^{39}$ Importantly, the drilling and extraction of natural gas may also lead to 'fugitive' methane emissions, which are in fact 34 times stronger than $\mathrm{CO}_{2}$ emissions at trapping heat over a hundred-year period. ${ }^{40}$ The safety of natural gas extraction is therefore vital to any claimed benefits over other energy sources, such as coal. This appears to be recognized by the Resolution's requirement that natural gas be sourced from 'safe and secure supply and produced according to the highest possible standards' ${ }^{41}$ The EU's independent role in ensuring the safety of offshore oil and gas operations is discussed further below. The EU further 'supports the step-by-step precautionary approach in the development of

37 A Stępien and A Raspotnik, The EU's New Arctic Communication: Not-so-integrated, Not-so-Disappointing?, Arctic Centre, University of Lapland (2 May 2016), available at: http://lauda.ulapland.fi/bitstream/handle/10024/62370/ArCticles-1-2016-EU-ArcticPolicy-StepienRaspotnik.pdf?sequence=5, accessed 28 July 2016; See also K Offerdal, 'An EU Arctic Policy?' (Geopolitics in the High North, 2012) available at: http://www.geo politicsnorth.org/index.php?option $=\mathrm{com}_{-}$content\&view $=$article\&id $=156$ :an-eu-arcticpolicy\&catid=39\&Itemid $=107$, accessed 28 July 2016 .

38 European Parliament 'Resolution on EU Strategy for the Arctic' (Resolution) 2013/2595(RSP), 12 March 2014, para. 55 .

39 Union of Concerned Scientists, 'Environmental Impacts of Natural Gas', available at: http://www.ucsusa.org/clean-energy/coal-and-other-fossil-fuels/environmental-im pacts-of-natural-gas\#.WDK38ebhDIU; accessed 28 July 2016. Ibid.

41 European Parliament, 'EU Strategy for the Arctic', Resolution 2013/2595(RSP), para. 55. 
energy resources in the Arctic, recognizing that the regions of the Arctic differ substantially'.42

Although these statements endeavour to provide checks and balances, they remain quite vague in content, without providing a clear indication of how they should be translated into the EU's own policy. The further development of an integrated EU position on the Arctic provided a valuable opportunity for the EU to set out more concrete action for climate change mitigation and adaptation in the Arctic.43 This position has now been published in the 2016 Communication on an Integrated European Union Policy for the Arctic, which certainly places climate change at the forefront. ${ }^{44}$ The Communication, which at the time of writing is expected to be taken over by the Council, is now explored in more detail below. ${ }^{45}$

\section{Climate Protection in the Integrated European Union Policy for the Arctic'}

In their 2016 Joint Communication on an Integrated European Union Policy for the Arctic, the Commission and the High Representative of the Union for Foreign Affairs and Security Policy presented the much anticipated 'priority areas' of the EU's unified Arctic policy. ${ }^{46}$ First among them is 'climate change and safeguarding the Arctic environment', which is followed by 'sustainable development in and around the Arctic', and 'international cooperation on Arctic issues'. The Communication notes that, whereas 'in the past attention focused

42 Ibid. See also, 'Council Conclusions Developing a European Union Policy towards the Arctic Region', Foreign Affairs Council Meeting, Brussels (12 May 2014), paras 6, 7. In particular, the EU continued to push for the Imo's adoption of the Polar Code, yet this was mainly focussed on ship pollution from oil, noxious discharges, sewage and garbage. The Polar Code was successfully adopted by the IMO at the 2015 MEPC 68 , available at: http://www.imo.org/en/MediaCentre/PressBriefings/Pages/18-Polar-Code-MEPC.aspx; accessed 28 July 2016.

43 H Hoag, 'The EU Unveils its Arctic Strategy', available at: https://www.newsdeeply.com/ arctic/articles/2016/05/11/the-e-u-unveils-its-arctic-strategy; accessed 11 May 2016.

$44 \operatorname{JOIN}(2016) 21$ (n 1$)$.

45 See Stępień and Raspotnik (n 37) at p. 4, noting that: 'The Joint Communication is not a definite statement of the EU's policy towards the Arctic as it - in principle - is to inform other EU institutions on the position of the Commission and the HR. Nonetheless, it can be considered as an authoritative guidance to Commission services and it is likely to be endorsed by the Council'.

46 Notably, Hoag (n 43), suggests that several 'internal factors' may also have stimulated the development of the Eu's integrated policy, including questions of inter-agency rivalry, what to do after the last enlargement, and the geographical balance within the EU. 
almost solely on the effects of climate change in the Arctic', there is now 'growing awareness that feedback loops are turning the Arctic into a contributor to climate change. ${ }^{47}$ The greenhouse gases escaping the thawing permafrost are capable of releasing amounts of carbon dioxide and methane 'equivalent to several times today's annual greenhouse gas emissions from man-made sources such as fossil fuel use.48 Thus, as noted by the European Climate Research Alliance (ECRA), there is increasing recognition that 'what happens in the Arctic does not stay in the Arctic'49

A core element of the EU's policy response to climate change is 'a better understanding of the developments in the region' through climate research. ${ }^{50}$ The Communication expects the EU to 'maintain its current level of funding levels for Arctic research [...] under the Horizon 2020 Program', having committed $€_{40}$ million for the $2016-2017$ work program. ${ }^{51}$ Among others, this research will be channelled through the EU-Polar Net Initiative, which aims to better 'assimilate Europe's scientific and operational capabilities in the Polar Regions'.

In setting out the mitigation and adaptation strategies, the 2016 Communication reiterates the EU's pledge under the Paris Agreement to achieve a $40 \%$ reduction in GHG emissions by 2030 compared to 1990 levels. ${ }^{52}$ It also reaffirms the EU's commitment to spend $20 \%$ of its budget on climaterelated activities. It does not, however, specify to what extent these overarching reduction commitments will be directed towards the Arctic region. In this regard, it appears that the $\mathrm{EU}$ is waiting on other actors, being 'ready to work with Arctic States, indigenous peoples and the relevant regional and multilateral fora', to develop an 'ambitious climate adaptation agenda for the Arctic

$47 \operatorname{JOIN}(2016) 21$ (n 1), at 5 (emphasis added).

48 Ibid., referring to the International Panel on Climate Change's Fifth Assessment Report (AR5), available at: https://www.ipcc.ch/report/ar5/; accessed 11 May 2016. Permafrost temperatures have increased in most regions since the early $1980 \mathrm{os}$.

49 'Arctic ECRA: Strategy and Work Plan', available at: http://www.ecraclimate.eu/images/ documents/Arctic\%20ECRA\%20SW_Plan.pdf; accessed, 11 May 2016. The ECRA is a coordinating institution, made up of 'partner' research organisations, aimed at streamlining and optimising national and European climate research programmes. See further: http:// www.ecra-climate.eu/about-us/governance; accessed 11 May 2016.

$5^{\circ} \operatorname{JOIN}(2016) 21(\mathrm{n} 1)$, at $5^{-7}$.

$51 \quad$ Ibid., at p. 6.

$5^{2} \quad$ Ibid. 
region' ${ }^{53}$ This could be channelled in part through the European Structural and Investment Funds (ESIF), 'which mainstream climate action'. ${ }^{4}$

The 2016 Communication does mention oil and gas activities, with regard to which the EU is 'committed to working closely with Member States, the OSPAR Convention and other stakeholders' ${ }^{5}$ However, this cooperation is directed at promoting the adoption of 'the highest standards of major accident prevention and environmental control', and not specifically at the regulation of consumption from the Arctic region. This was something of a disappointment from an environmental perspective. The director of the Global Arctic Program at the World Wide Fund for Nature (WWF), Alexander Shestakov, for example, was 'expecting the E.U. to say that it did not want oil and gas from the Arctic and that it was not interested in supporting E.U.-based companies doing those projects in the Arctic.56 There is also a lack of explicit support for a ban on the use of heavy fuel oil by the shipping sector in the Arctic, which, as noted by Shestakov, is a program already adopted by the Arctic Council. ${ }^{57}$ In March 2017, concerned Members of the European Parliament submitted a nonbinding motion calling for a total ban on oil drilling in the Arctic; 58 however, this was rejected by the European Parliament in a symbolic vote that could 'set the tone' for Brussels policy, just as Norway announced plans to open up a record number of blocks in Arctic waters for hydrocarbon exploration. ${ }^{59}$

Another issue is that of black carbon emissions, to which, as discussed, the $\mathrm{EU}$ is one of the largest contributors. ${ }^{60} \mathrm{EU}$ Member States are party to the

53 Ibid., at p. 7 .

54 Ibid.

55 Ibid., at p. 8.

56 See Hoag (n 43).

57 Ibid.

58 European Parliament News, 'Arctic: ban oil drilling and mitigate tensions, urge MEPs' (16 March 2017), available at: http://www.europarl.europa.eu/news/en/news-room/ 20170308IPR65674/arctic-ban-oil-drilling-and-mitigate-tensions-urge-meps; accessed 20 June 2017.

59 P Bertrand, 'EU Parliament Rejects Total Ban on Arctic Oil Drilling' (17 March 2017), available at: http://www.euronews.com/2017/03/17/eu-parliament-rejects-total-ban-on-arcticoil-drilling; accessed 20 June 2017.

6o The Eu's lack of ambition on this front was even brought to the attention of certain industry associations, which called upon it to integrate specific measures into its emissions ceilings Directives, and to support the broadening of the Gothenburg Protocol on Transboundary Air Pollution to include black carbon, see, 'Black Carbon and Global Warming' (2010), available at: http://www.aegpl.eu/lpg-eu-policy/black-carbon.aspx; accessed 20 June 2017 . 
Gothenburg Protocol to the Convention on Long-Range Transboundary Air Pollution (CLRTAP), which sets emission ceilings for certain harmful pollutants, and was amended to include black carbon in $2012 .{ }^{61}$ However, at the time, the national reduction commitments were far from ambitious, and most states agreed to ceilings no higher than the business-as-usual scenario in which merely existing legislation would be implemented. ${ }^{62}$ The 2016 Communication does not provide a clear path to improvement, stating quite generally that the EU should 'contribute to international efforts to limit emissions of short-lived climate pollutants such as black carbon and methane. ${ }^{63}$ Simply enumerating possible agreements, it is suggested that the EU could limit emissions through: the CLTRAP, the amended Gothenburg Protocol, the Commission's Air Quality Package proposal, the Climate and Clean Air Coalition and 'engagement with Arctic Council initiatives such as the Task Force on Black Carbon and Methane. ${ }^{64}$

From the above analysis it appears that the EU's concrete policy suggestions may not be as ambitious as they could be. Still, the EU evidently does consider climate protection to be a core element of its Arctic policy. This is particularly clear when we look at the EU energy policy in the Arctic context. Indeed, this is one area in which the EU may have somewhat more room to manoeuvre amongst the other Arctic actors. The following section explores this policy, highlighting how EU energy priorities in the Arctic have changed over time. Here, a particular point of emphasis is the changing attitude of the EU towards the management and exploitation of hydrocarbon resources in the Arctic.

\section{The EU Energy Policy in the Arctic: A Climate Focus-Shift in 2016}

Complementing and sometimes competing with the EU's climate objectives is the EU's energy policy in relation to the Arctic region. Looking at the 2016 Communication, it would appear that the focus of $\mathrm{EU}$ attention in energy matters in the Arctic has shifted. Even though the EU has a strategic interest in

61 UNECE, 'Parties to UNECE Air Pollution Convention approve new emission reduction commitments for main air pollutants by 2020' (4 May 2012), available at: http://www .unece.org/index.php?id=29858; accessed 20 June 2017.

62 Air Pollution and Climate Secretariat, 'New Gothenburg Protocol Adopted', available at: http://www.airclim.org/acidnews/new-gothenburg-protocol-adopted; accessed 20 June 2017.

$63 \operatorname{JOIN}(2016) 6$.

64 Ibid., at p. 7 . 
the oil and gas supply from the Arctic, ${ }^{65}$ the 2016 Communication focuses on renewable energy development, on the Green Economy and on the so-called Blue Economy. ${ }^{66}$ As discussed, hydrocarbons are only mentioned in the integrated policy for the Arctic to promote the adoption of 'the highest standards of major accident prevention and environmental control, ${ }^{67}$ and there is no mention of the regulation of production and consumption of oil and gas from the Arctic region. The content of the 2016 Communication thus strikingly differs from preceding policy documents and represents an important focus shift in the policy priorities of EU in the Arctic. That being said, in analysing to what extent the EU is truly playing an assertive role in relation to energy and the Arctic, it is valuable to devote further attention to the Eu's own domestic action in this field. The following section first explores the developments leading towards a greater climate focus in EU energy policy. The extent to which this shift is reflected in EU domestic policy is then analysed, with a focus on the 2013 Offshore Safety Directive, and the ways in which it indirectly extends its reach to the Arctic region. ${ }^{68}$

The interest of the EU in the energy resources located in the Arctic, and more generally in the 'High North', emerged during the British Presidency in 2005. ${ }^{69}$ This was clearly visible in the 2006 renewal of the Northern Dimension (ND) policy, ${ }^{70}$ where one of the main priorities was to enhance "cooperation in the field of energy efficiency and renewable energy'.71 The framework document

65 An estimated one quarter of oil and gas produced in the Arctic ends up in the Eu. See G Stang, 'EU Arctic Policy in a Regional Context', European Parliament DirectorateGeneral for External Policies, (July 2016) EP/EXPo/B/FWC/AFET/2015-01/03, 24, available at: http://www.europarl.europa.eu/RegData/etudes/STUD/2016/578017/EXPO_ TU(2016)578017_EN.pdf; accessed 20 June 2017.

$66 \operatorname{JOIN}(2016) 21$ (n 1), at 9.

67 Ibid., at p. 8.

68 Directive 2013/30 on the safety of offshore oil and gas operations, OJ L 178/66, 28 June 2013.

69 K Offerdal, 'Arctic Energy in Eu Policy: Arbitrary Interest in the Norwegian High North', (2010) 63(1) Arctic 30-42, at p. 34.

70 The Northern Dimension Initiative (ND) was initially launched in 1999 with the aim to provide a framework to 'promote dialogue and concrete cooperation;' 'strengthen stability, well-being and intensified economic cooperation;' and 'promote economic integration, competitiveness and sustainable development in Northern Europe'. The ND is a joint policy between the EU, Russia, Norway and Iceland. For more information, please refer to https://eeas.europa.eu/headquarters/headquarters-homepage/347/northerndimension_en; accessed 20 June 2017.

71 Political Declaration on the Northern Dimension Policy (Helsinki, 24 November 2006) available at: http://collections.internetmemory.org/haeu/20160313172652/http://eeas .europa.eu/north_dim/docs/nd_political_declaration_2006_en.pdf; accessed 20 June 2017. 
of the ND policy again places an emphasis on economic cooperation in the field of energy, the protection of the Arctic ecosystems, and cooperation in the field of climate change and environmental legislation. ${ }^{72}$ In parallel to this regional cooperation policy, the EU developed its Arctic policy where energy concerns were consolidated as one of the priorities for the region. In the 2008 Communication, energy production in the Arctic is part of two of three main policy objectives listed. ${ }^{73}$ In particular the section dedicated to the second policy objective, namely the promotion of the sustainable use of resources, opens with a paragraph on 'Hydrocarbons. ${ }^{74}$ Notably, the communication was adopted in the same year in which the us Geological Survey published its famous study in which it estimated that around $10 \%$ of world's undiscovered oil and gas resources might be located in the Arctic. ${ }^{75}$ Accordingly, as mentioned, the 2008 Communication affirms that 'Arctic resources could contribute to enhancing the EU's security of supply concerning energy.' ${ }^{76}$ The Communication moreover states EU support for the exploitation of hydrocarbons 'in full respect of strict environmental standards taking into account the particular vulnerability of the Arctic. ${ }^{77}$

A similar position was expressed in the 2012 Communication, where the EU proclaimed in particular its role as a 'major destination of resources and goods from the Arctic region.78 The pursuit of high environmental standards and the protection of the vulnerable Arctic system was at that moment strengthened by the provisional observer status of the EU at the Arctic Council, and its contribution to the work of the Arctic Council's Protection of the Arctic Marine Environment Working Group. ${ }^{79}$ The paragraph on the sustainable

72 Northern Dimension Policy Framework Document (Helsinki, 24 November 2006) available at: http://collections.internetmemory.org/haeu/20160313172652/http://eeas.europa.eu/ north_dim/docs/nd_framework_document_2006_en.pdf; accessed 20 June 2017.

The three main policy objectives are: protecting and preserving the Arctic in unison with its population, promoting sustainable use of resources, and contributing to enhanced Arctic multilateral governance; $\operatorname{com}(2008) 763$ (n 2), para. 1, at p. 3 . $\operatorname{com}(2008) 763$ (n 2), para. 3.1, at p. 6-7.

75 KJ Bird, RR Charpentier, DL Gautier, DW Houseknecht, TR Klett, JK Pitman, TE Moore, CJ Schenk, ME Tennyson, and CJ Wandrey, 'Circum-Arctic Resource Appraisal: Estimates of Undiscovered Oil and Gas North of the Arctic Circle' (2008) U.s. Geological Survey, Fact Sheet 2008-3049, available at: https://pubs.usgs.gov/fs/2008/3049/; accessed 20 June 2017.

$76 \operatorname{com}(2008) 763(\mathrm{n} 2)$, para. 3.1, at p. 6.

77 Ibid., at p. 7 .

78 JoIn(2012) 19 final, at p. 3; see also ibid., at p. 9 in fine.

79 Ibid., at p. 12; On the Arctic Council's Protection of the Arctic Marine Environment Working Group, see the website of the Working Group: http://www.arctic-council.org/ index.php/en/about-us/working-groups/pame; accessed 20 June 2017. 
management and use of resources opens with the aim of 'increasing mining and oil extraction activities in the Arctic region, ${ }^{\prime 80}$ and closes with the commitment of the EU to 'explore further potential economic activities, such as the further development of the (...) renewable energy [sector]'. ${ }^{81}$ The connection with the EU energy policy and the strategic importance of the Arctic region is highlighted in the 2012 Communication by its reference to the Commission Communication 'EU Energy Policy: Engaging with Partners beyond Our Borders' $^{\prime 2}$ and the on-going drafting of what will then be the 2013 Directive on the safety of offshore oil and gas operations. ${ }^{83}$

In its Resolution of 12 March 2014 on the EU strategy for the Arctic, the European Parliament put particular emphasis on the environmental concerns related to offshore oil and gas exploitation in the Arctic, and how the 2013 Directive provided a much-needed 'effective response' ${ }^{84}$ Unfortunately, the 2013 Directive was not well received in the Arctic region. ${ }^{85}$ Not surprisingly, the 2016 Communication does not really address the EU Parliament's concerns about the safety of offshore oil and gas operations. There is only one reference to the 2013 Directive, in a footnote, ${ }^{86}$ as example of regulatory best practice that the EU is willing to share with its international partners in order to 'support the safety and preservation of the environment in the region: ${ }^{87}$ Moreover, the section on the sustainable management of the region mentions the existence of hydrocarbons but does not pursue the discourse on their role for the EU energy security that we find in the preceding policy documents.

As highlighted above, the 2016 Communication gives voice to the developments which occurred in Paris in 2015 and to the imperatives of decarbonizing our economies. Consequently, its energy chapter focuses on development of renewable energy projects in the Arctic and seems to somewhat marginalize the oil and gas sector. This, however, cannot only be explained by the impact

\footnotetext{
8 Ibid., at p. 9 .

81 Ibid., at 10.

$82 \quad \operatorname{com}(2011) 539$ of 7 September 2011.

83 Directive 2013/30 on the safety of offshore oil and gas operations, OJ L 178/66, 28 June 2013. The relevance of this Directive for the Arctic region will be discussed below.

84 European Parliament, Resolution of 12 March 2014 on the EU strategy for the Arctic, para. 15 .

85 As members of the European Free Trade Association, Norway and Iceland apply most EU legislation related to the single market. They, however, decided not to apply the 2013 Directive. In particular, Norwegian authorities consider that the 2013 Directive falls outside the scope of application of the EFTA because of its application to the continental shelf of coastal states. See EU Arctic Policy in Regional Context (n 6o) at p. 25.

$86 \operatorname{JOIN}(2016) 21$ (n 1), at p. 8, footnote 22.

87 Ibid.
} 
of the climate negotiations. The difficult relationship with Russia in the last years and the rejection by EFTA (European Free Trade Association) Arctic states of the 2013 Directive $^{88}$ are also part of the equation. Nevertheless, the 2013 Directive remains a core element of the EU energy policy and has a considerable potential impact on the relationship between the EU and the Arctic states, ${ }^{89}$ as we show below.

\section{The Reach of EU Energy Legislation in the Arctic: The 2013 Offshore Safety Directive ${ }^{90}$}

Drafted at a moment when hydrocarbons were still high on the agenda of the EU Arctic policy, the 2013 Offshore Safety Directive was the first piece of legislation specifically tackling the offshore oil and gas sector, and thus had to contain references to the Arctic. We highlight below how the Directive extends its reach to the Arctic region, even though it is not directly applicable to the Arctic waters. The Directive shows how the EU can push forward its policy objectives through secondary legislation, in this case in the energy sector, but perhaps in the future also in the field of climate change.

The Directive contains three different types of references to the Arctic region. First, it includes specific references to the Arctic waters. Second, it deals with transboundary situations which could potentially involve the Arctic region. Third, it encourages EU private economic actors to conduct their business responsibly also outside the EU territory, including in the Arctic waters.

\section{Specific References to the Arctic Waters in the 2013 Directive}

Even though EU coasts do not border Arctic waters, the EU extends its sphere of influence and its energy and climate agendas through its secondary legislation, such as the 2013 Offshore Safety Directive. The 2013 Directive refers to the Arctic in two parts. First, in paragraph $5^{2}$ of its Preamble it affirms that:

The Arctic waters are a neighboring marine environment of particular importance for the Union, and play an important role in mitigating climate change. (...) Member States who are members of the Arctic Council are

88 European Parliament (n 81).

$89 \quad E U$ Arctic Policy in Regional Context (n 6o) at p. 25.

9o Some of the arguments of this section have been previously presented in C Cinelli and S Trevisanut, 'The safety of Arctic Offshore Oil and Gas Operations within the EU Regulatory Framework' (2016) 14(2) Journal of Oil and Gas Law 1-13. 
encouraged to actively promote the highest standards with regard to environmental safety (emphasis added).

The EU thus reaffirms its proximity to the Arctic region in order to justify its interest in playing a role. This argument also underlies the EU concerns in potential transboundary situations, as is pointed out below, and pressures the three EU Arctic Member States, i.e., Finland, Sweden and Denmark, ${ }^{91}$ to promote EU policy within the Arctic Council. Paragraph $5^{2}$ also stresses how the 'serious environmental concerns relating to the Arctic waters require special attention to ensure the environmental protection of the Arctic in relation to any offshore oil and gas operation, including exploration, taking into account the risk of major accidents and the need for effective response'. As discussed above, particularly in relation to natural gas, accidents and leakages during the extraction process may greatly contribute to the release of harmful GHGs. The protection of the Arctic waters is then a mitigation mechanism in itself, and thus a key EU objective in its climate leadership.

Article 33 of the Directive on 'Coordinated approach towards the safety of offshore oil and gas operations at international level' then directly refers to the Arctic. This Article provides that the European Commission, in close collaboration with Member States, promotes cooperation with third countries 'that undertake offshore oil and gas operations in the same marine region' as Member States. This cooperation includes the exchange of information between the member state and the adjacent third states in order to 'promote preventive measures and regional emergency response plans' (para. 2). More specifically, ' $[\mathrm{t}]$ he Commission shall promote high safety standards for offshore oil and gas operations at international level in relevant global and regional fora, including those relating to Arctic waters' (para. 3, emphasis added). It is important to underline that the European Commission is a Member of all sub-circumpolar councils, whereas the EU still has no direct role in the Arctic circumpolar cooperation on the Arctic Council. The EU has not obtained the formal status of permanent Observer of the Arctic Council yet. ${ }^{92}$ However, the

91 For Denmark see (n 14).

92 The 2013 Kiruna Declaration provides that: 'The Arctic Council receives the application of the EU for observer status affirmatively, but defers a final decision on implementation until the Council ministers are agreed by consensus that the concerns of Council members, addressed by the President of the European Commission in his letter of 8 May are resolved, with the understanding that the EU may observe Council proceedings until such time as the Council acts on the letter's proposal'; Arctic Council, Kiruna Declaration, Kiruna, Sweden, 15 May 2013, at 8, available at: https://oaarchive 
EU is present within the Arctic Council Working Groups and participates in the Arctic Council ministerial meetings as an ad hoc observer. ${ }^{93}$

In relation to the geographical scope of the Directive, paragraph 50 of the Preamble refers to 'the four marine regions identified in Article 4(1) of Directive 2008/56/EC, ${ }^{94}$ namely the Baltic Sea, the North-east Atlantic Ocean, the Mediterranean Sea and the Black Sea. ${ }^{95}$ The express reference to the Arctic waters in Article 33 clarifies the extent of the cooperation, the marine regions targeted by the provision and the role of the Commission in this respect. Notably however, Article 33 is part of Chapter viII of the Directive on 'Transboundary Effects' and not of Chapter VI on 'Cooperation', ${ }^{96}$ as originally provided in the 2011 regulation proposal. ${ }^{97}$ Hence it could be argued that such cooperation concerns only transboundary situations involving the Arctic waters.

\section{Transboundary Situations (Potentially) Involving Arctic Waters}

Pursuant to Article 31 of the Offshore Safety Directive,

$[\mathrm{w}]$ here there is a risk of the foreseeable transboundary effects of major accidents affecting third countries, Member States shall, on a reciprocal basis, make information available to the third countries (para. 3, emphasis added).

.arctic-council.org/bitstream/handle/11374/93/MMo8_Kiruna_Declaration_final_ formatted.pdf?sequence=5\&isAllowed=y; accessed 20 June 2017 .

93 See Rule 37 of the Rules of Procedure as adopted by the Arctic Council at the first Arctic Council Ministerial Meeting (1998) and revised at the Kiruna Arctic Council Ministerial Meeting (2013). The rules of procedure are available at: http://www.arctic-council.org/ index.php/en/our-work2/8-news-and-events/345-popular-documents; accessed 20 June 2017.

94 Directive 2008/56/EC of the European Parliament and of the Council of 17 June 2008 establishing a framework for community action in the field of marine environmental policy, OJ L 164/19, 25 June 2008.

95 Pursuant to para. 50 of the Directive's Preamble, '[i]n implementing the obligations under this Directive, account should be taken of the fact that marine waters covered by the sovereignty or sovereign rights and jurisdiction of Member States form an integral part of the four marine regions identified in Article 4(1) of Directive 2008/56/EC, namely the Baltic Sea, the North-east Atlantic Ocean, the Mediterranean Sea and the Black Sea. For this reason, the Union should, as a matter of priority, strengthen coordination with third countries that have sovereignty or sovereign rights and jurisdiction over marine waters in such marine regions'.

96 Chapter vi now includes a single article, Article 27, regulating the cooperation between Member States.

$97 \quad \operatorname{com}(2011) 688$ final Annex I, 35 . 
The duty to cooperate in transboundary situations is a well-established principle of international law and, specifically, of the law of the sea. Spelled out in general terms in Article 197 Law of the Sea Convention (LOSC), ${ }^{98}$ Article 198 LOSC clearly provides that " $[\mathrm{w}]$ hen a State becomes aware of cases in which the marine environment is in imminent danger of being damaged or has been damaged by pollution, it shall immediately notify other States it deems likely to be affected by such damage, as well as the competent international organizations'. The obligation to notify and thus, in a large extent, to exchange information is not submitted to reciprocity as indicated in Article 31 of the Directive. Under international law, states have an obligation to cooperate independently of the behaviour of the interested third state. To limit this obligation on a reciprocal basis can be considered a violation of international law.

The condition of reciprocity, however, disappears in paragraph 6 of the same provision, which states that: 'In the event of a major accident, or of an imminent threat thereof, which has or is capable of having transboundary effects, the Member State under whose jurisdiction the situation occurs shall, without delay, notify the Commission and those Member States or third countries which may be affected by the situation and shall continuously provide information relevant for an effective emergency response'. It is then not clear to what extent the reciprocity condition operates in relation to the exchange of information and notification.

Article 31 of the Directive contains other unsettling elements. The wording of its paragraph 4 remains particularly ambiguous: 'Member States shall coordinate between themselves measures relating to areas outside of the Union in order to prevent potential negative effects of offshore oil and gas operations' (emphasis added). Notably, Article 31 of the Directive concerns transboundary emergency preparedness and response of Member States with offshore oil and gas operations under their jurisdiction. Hence, paragraph 4 could be interpreted as referring to measures adopted in fora where EU Member States are involved in relation to areas outside the EU, such as the Arctic Council. In this context, one could wonder whether the EU Arctic states are supposed to coordinate only between themselves or whether they should also involve other EU Member States which might suffer negative effects of offshore oil and gas operations under their jurisdiction because of the adopted measures. The implementation of the present provision is utterly unclear.

98 United Nations Convention on the Law of the Sea (LOSC) (Montego Bay, 10 December 1982, in force 16 November 1994) 1833 UNTS 396. 


\section{EU Private Actors Operating in the Arctic}

The Offshore Safety Directive advocates the need for a more active role of the industry in guaranteeing the safety of offshore platforms, in particular by better monitoring the construction and operation of the installations. ${ }^{99}$ It specifically affirms:

Best global practice requires licensees, operators and owners to take primary responsibility for controlling the risks they create by their operations, including operations conducted by contractors on their behalf and therefore to establish within a corporate major accident prevention policy the mechanisms and highest level of corporate ownership to implement that policy consistently. ${ }^{100}$

In Article 2(5), the Directive defines the operator as the 'entity appointed by the licensee or licensing authority to conduct offshore oil and gas operations, including planning and executing a well operation or managing and controlling the functions of a production installation'. It also defines the licensee, namely the 'holder or joint holders of a license', 101 the contractor, i.e., an 'entity contracted by the operator or owner to perform specific tasks on behalf of the operator or owner', ${ }^{102}$ and the owner, i.e., 'an entity legally entitled to control the operation of a non-production installation. ${ }^{103}$ Moreover, the same Directive translates into legal terms the concept of 'industry', which consists of 'entities that are directly involved in offshore oil and gas operations covered by the Directive or whose activities are closely related to those operations. ${ }^{104}$ This definition is novel and suggests a wide understanding of industry, which

99 The role of private actors has become a key issue in the relation to the safety of offshore activities. Apart from the Offshore Safety Directive, several other instruments at the international, supranational and national level adopt a similar approach. In this regard, see A Bonfanti and F Romanin Jacur, 'Energy from the Sea and the Protection of the Marine Environment: Treaty-Based Regimes and Ocean Corporate Social Responsibility' (2014) 29 International Journal of Marine and Coastal Law 622-644; S Trevisanut, 'The Role of Private Actors in the Offshore Energy Industry' (2014) 29 International Journal of Marine and Coastal Law 645-665.

100 Preamble, para. 36, emphasis added.

101 Art. 2(11). A licence is 'an authorization for offshore oil and gas operations pursuant to directive 94/22/EC'. (Art. 2(9)).

102 Art. 2(12).

103 Art. 2(27).

104 Art. 2(35). 
encompasses not only the oil and gas companies but also any material or service provider whose activities are 'closely related' to the oil and gas operations.

The Directive encourages a certain extra-territorial application of the primary responsibility of EU economic actors. It calls on Member States to 'require reports on major accidents occurring outside the Union [e.g., in Arctic waters] which involve companies registered in their territory, and should share this information at Union level' (Preamble, para. 39, emphasis added). Moreover,

[w]hile Member States are not able to enforce rules outside the Union, [adequate means for the confidential reporting of safety concerns] should enable the reporting of concerns of persons involved in offshore oil and gas operations outside the Union (Preamble, para. 41, emphasis added).

Art. 20 of the Directive provides for an obligation on Member States to 'require companies registered in their territory and conducting, themselves or through subsidiaries, offshore oil and gas operations outside the Union, as licence holders or operators to report to them, on request, the circumstances of any major accident in which they have been involved' (emphasis added).

By directly addressing their role, the Offshore Safety Directive strives to promote and enhance the safety culture of EU economic actors. Moreover, the 'primary responsibility' of EU private actors acting outside the EU is also limited to situations where major accidents occur. The Eu legislator lost an important opportunity to remind the business sector of its fundamental role in the protection of the environment, ${ }^{105}$ and to stress the importance of private regulatory efforts, such as corporate social responsibility instruments.

\section{Conclusions}

Although the Eu likes to profile itself as the 'architect' of the Paris Agreement, its climate policy in the Arctic region does not seem to have followed an equally ambitious trajectory. ${ }^{106}$ As such, it is perhaps not surprising that the EU's

105 As rightly pointed out by Brunnée and Hey: 'it is not states that are most directly impacted by or directly cause degradation and resources scarcity, but individuals and groups in society, such as farmers or industries'; J Brunnée and E Hey, 'Transparency and International Environmental Law' in A Bianchi and A Peters (eds), Transparency in International Law (Cambridge University Press, Cambridge, 2013) 23-48, at p. 26.

106 For more detailed analysis of individual Eu Arctic states see Airoldi (n $3^{2}$ ) at p. 46. 
Integrated Policy on the Arctic has had a somewhat critical reception. Stępień and Raspotnik, for example, describe the 2016 Communication as 'a list of numerous activities, studies, and projects that have already taken place', which 'provides fairly few examples of actions yet to be taken'. ${ }^{107}$ The authors argue that 'the Communication does not deliver on the promise included in its title' to 'establish a truly "integrated EU Arctic policy". Encompassing 'too many diverse issues' of both an internal and external nature, the policy is 'too marginal' for the EU to realistically aim at its envisaged integration. ${ }^{108}$

While it is certainly conducive to climate protection, the greater focus on, among others, innovation and cold climate technologies has been explained by the EU's move away from 'overblown expectations of rapidly expanding maritime shipping and hydrocarbon extraction. ${ }^{\prime} 109$ In fact, in light of the Eu's struggles to position itself on the Arctic scene, science 'seems to be the internally agreed-on key that aims to finally open the Arctic governance/cooperation door for the Union'. In this regard, the Eu's 'unfortunate stalemates' in reaching international cooperation have led to an 'overall cautious approach that rather defines the Union as Arctic suppliant than equal Arctic actor.'110

The difficulties at the international level do not, however, prevent the EU from elaborating secondary legislation which carries forward its own climate and energy agenda. The above-analysed 2013 Offshore Safety Directive is a perfect example. Still, the hostile reaction of the EFTA Arctic states to this Directive shows the limits of such an approach. Furthermore, one could question the EU's ambition in relation to its overall energy consumption sourced from the Arctic, which is an important indirect contributor to climate and environmental harm. In the face of these obstacles and contradictions, the EU continues to struggle to fulfil its own climate leadership aspirations in the Arctic. It is to be hoped that the increased environmental emphasis of its new integrated policy may at least provide some firmer ground for further growth as an Arctic actor.

\footnotetext{
107 Stępień and Raspotnik (n 37) at p. 5.

108 Ibid.

109 Ibid., at p. 19.

110 Ibid., at p. 17; see also Hossain (n 23).
} 